\title{
Evaluating Benefits of Sport Mega-Events on the Host Cities: Effects of the 34th America's Cup on Naples
}

\author{
Rosa Caiazza \\ Parthenope University of Naples, Italy \\ Ioannis Minis \\ Aegean University, Chios, Greece
}

\begin{abstract}
Sport tourism events refer to sport activities with potential to attract tourists, media, athletes, and other sporting officials, with the primary purpose for travel being participating in or viewing sport. Sport mega-events, such as America's Cup, have been recognized as a strong component of tourism, and are becoming an integral and major part of tourism development and marketing strategies. As a catalyst for change, sport mega-events can accelerate the host city economic, political, and social development. This paper focuses on the case of the 34th America's Cup for Naples. In order to evaluate the benefits of this event on the city, the authors first propose a general framework of main benefits that sport mega-events may bring to host cities, and subsequently, the authors applied this framework to the Naples case.
\end{abstract}

Keywords: America’s Cup, tourism management, sport mega-events

\section{Introduction}

Sport events, which attract people from different places and countries are becoming an integral part of tourism development and marketing strategies for the host cities (Getz, 1997). Major sporting events, such as the Olympic Games, FIFA World Cup, and America's Cup can be a significant catalyst for change, elevating the host city's global stature and changing its economic, political, and social development. Hosting a sport event provides a city the opportunity to mobilize quickly on a wide range of issues and activities that would normally be mired in endless debates and bureaucracy. It provides a rigid deadline and an impetus that accelerates infrastructure development and other large-scale improvement activities that might otherwise take decades to complete. The process of pursuing and delivering a major event fosters collaboration among the public and private sector. It breaks down the barriers between political parties and between various levels of government. It improves government efficiency and sets an example for new ideas and behaviors such as agency integration, environmental sustainability, diversity, and community involvement. In order to capitalize

Rosa Caiazza, Ph.D., Assistant Professor, Department of Business Studies, Parthenope University of Naples, Visiting Researcher at Wharton Business School of University of Pennsylvania and Univeristè Libre de Bruxelles.

Ioannis Minis, Professor, Department of Financial and Management Engineering, Aegean University.

Correspondence concerning this article should be addressed to Rosa Caiazza, via Medina 40, 80133, Napoli (IT). E-mail: rosa.caiazza@uniparthenope.it. 
on these benefits, a host city (or even a host country in the case of smaller countries) should develop a robust legacy plan, which is fully evaluated in terms both of financial and economic costs and benefits. This plan should be aligned with the city's strategy and long-term development goals and plans. Finally, its implementation needs to be managed closely.

This study proposes a targeted framework for capturing the main benefits of hosting a sport mega-event based on previous experience. Subsequently, it validates this proposal by applying the framework to the case of the 34th America's Cup of Naples. To establish our proposals, the authors considered relevant literature and used an analysis of the effects of significant sport mega-events on the related host cities. Data on the 34th America's Cup were collected through a desk analysis of main articles reporting official and public interviews of city’s leaders. Furthermore, direct observations were carried out throughout the event.

\section{Benefits of Sport Mega-Events on a Host City}

Significant research has focused on the positive impacts of mega-events on hosting cities (Getz, 1997; Hall, 1989; Kang \& Perdue, 1994; Murphy \& Carmichael, 1991; Deccio \& Baloglu, 2002; Mihalik \& Simonette, 1998; Ritchie \& Aitken, 1984, 1985). The authors have employed the results of this work and their own research, experience, and observations to synthesize a framework of main benefits of hosting sport mega-events. This is presented in Table 1 and discussed below.

Table 1

Framework of Main Benefits of Hosting a Sport Mega-Event

\begin{tabular}{|l|l|}
\hline Credibility in the global marketplace & FIFA World Cup Germany 2006 \\
\hline Image of the government and leaders & $\begin{array}{l}\text { Pan American Games Rio 2007, FIFA World Cup Brazil } \\
\text { 2014, Olympics Rio 2016, London 2012 }\end{array}$ \\
\hline $\begin{array}{l}\text { Cooperation across political and government and between public } \\
\text { and private sectors }\end{array}$ & $\begin{array}{l}\text { Olympics Sydney 2000, Athens 2004, London 2012 } \\
\text { Games Glasgow 2014 1992, London 2012, Commonwealth }\end{array}$ \\
\hline Address social problems such as crime and urban decay & Olympics Sydney 2000, Beijing 2008 \\
\hline Opportunity to change & Olympics Munich 1972, Athens 2004, Beijing 2008 \\
\hline Infrastructure & Olympics Barcelona 1992 \\
\hline Jolt to the economy &
\end{tabular}

Firstly, hosting a major event gives the city instant visibility, and oftentimes long-term credibility, in the global marketplace. In the short term, a major sporting event also provides a showcase for all of the landmarks and exciting activities a host has to offer. It can put an unknown tourist destination on the map or it can help the city to be an established destination which improve its international image (Jeong \& Faulkner, 1996; Ritchie, 1984). For example, Germany has a global reputation for efficiency, engineering, and precision. But its motto for hosting the 2006 FIFA World Cup was "time to make friends" and that is exactly what it did. By the end of the tournament, many visitors and TV viewers were looking at Germany in a whole new light. In the long term, an appearance in the world stage can help the host attract new investment and companies to the area, and elevates the overall level of trade and business. This is in part due to the business opportunities that arise from staging the event, but it may also be attributed to the trust that the international awarding body places on the host city.

In addition to enhancing the image of the host city, or country, a major event may also benefit the image of 
the government and leaders who help make it happen (Hall, 1992). The previous Brazilian president enjoyed a significant surge in popularity and prestige for successfully attracting the 2007 Rio Pan American Games, the 2014 FIFA World Cup, and the 2016 Summer Olympics.

Internally, major events create a platform for unification and cooperation across political and government boundaries, and provide an opportunity for collaboration between the public and private sectors. The Sydney 2000 Olympics is an example of such collaboration between the organizing committee, businesses, and government agencies at the national, regional, and local level. What drove this collaboration in Sydney was the recognition that a special organizational structure was needed to ensure every major focus area had equal representation from both the organizing committee and government. The rigid requirements and deadlines associated with major events force government to take decisive action and operate more efficiently. Lessons and behaviors learned along the way can help the government improve how it operates in the future.

To improve their image and elevate their status, host cities and countries have a strong incentive to address social problems such as crime, poverty, and urban decay. Some choose to simply hide such problems from view, but others use the event as a catalyst to actually make things better. For example, the Barcelona Olympics turned a rundown part of the city into the event's crown jewel and made the city center more appealing by connecting it to the seafront and making the latter more accessible to citizens. A similar outcome was realized by the London 2012 Olympic Games, with the successful regeneration of a major area of East London. This successful paradigm is being currently followed by Glasgow 2014 for the upcoming Commonwealth Games.

A major event can provide an immediate jolt to the economy, but what really matters is the long-term impact (Getz, 1997; Hall, 1989; Kang \& Perdue, 1994; Murphy \& Carmichael, 1991; Deccio \& Baloglu, 2002). The activities and investments required before, during, and after an event can boost employment and create new business opportunities for a wide range of companies throughout the region. An improved global image may provide tourism and the local economy a significant and sustained boost as illustrated in the case of Barcelona with the 1992 Olympics. A relevant risk than should be mitigated is the potential significant drop in employment just before or immediately after the event. This may be due to two major reasons: (1) workforce involved in the infrastructure development, which is completed for the Games, will no longer be needed; and (2) operational Games staff that complete their duties (e.g., in the summer Olympic Games, 150,000 staff and volunteers work directly with the Organizing Committee). This mitigation may involves considerable planning by the government and the private sector, in close partnership.

Major events also provide an opportunity to improve resident life and change attitudes. A characteristic example is environmental sustainability (Deccio \& Baloglu, 2002). Sydney had promoted in its bid environmental concepts, and was selected as the host city of the 2000 Summer Olympic Games. Since then, the majority of major sport events have focused on sustainable development and environmental education. For the 2008 Olympic Games, Beijing wanted to reposition itself as more environmentally friendly and reconcile its rapid economic growth with an environmental protection policy that included pollution control and water conservation. Brazil has initiated a major program of relevant investments to significantly improve environmental conditions in Rio and other cities in view of the Brazil 2014 World Cup, and the Rio 2016 Olympic Games.

Previous studies suggest that one of the most significantly benefits of mega-events is lasting infrastructure 
and facilities created for the event and used by the citizens after the event (Mihalik \& Simonette, 1998; Ritchie \& Aitken, 1984; Ritchie \& Lyons, 1990). Major events, in fact, require significant infrastructure investments that can have a positive and lasting impact on the community. For example, the 1972 Olympics in Munich provided the impetus to build a subway system that continues to serve the city to this day. In Athens, the transport system was completely upgraded, by adding a new Airport, two new metro extensions, a new light rail, a new suburban railway, a new peripheral highway, and by completely upgrading an existing metro line as well as major road infrastructure. These enhancements drastically improved the city transport environment, addressing a major urban problem that was building up for decades. The improved infrastructure can attract new companies and enable people and businesses to operate more efficiently. Various large infrastructure projects and the redevelopment of entire city districts boost the city's long-term appeal for business and tourism.

The benefits from such infrastructure investments are maximized by aligning the infrastructural event needs, with mature investments already included in long term city master plans. Games requirements that do not fall in this category should be addressed by temporary inexpensive solutions, such as temporary facilities for venues, or special bus routes for transport. Misalignment of Games investments and long term city needs creates "white elephants", i.e., infrastructure and facilities with limited or minimal use for the city residents, and ultimately result in a waste of public resources. This, in turn, may reduce the attractiveness of the event in the future, and discourage cities for bidding as future hosts. Some of the major events globally are currently facing this issue, which is enhanced by the economic crisis.

\section{Effects of 34th Americas' Cup on Naples}

The America's Cup is the greatest sailing competition with a history extending back to 1851. The Cup was originally awarded to the victor of a special race of yachts of all nations in conjunction with the great exhibition of 1851. It started out as a fleet regatta, a race in which multiple competitors would participate simultaneously. After the first defense, however, and for the next 100 years or so, a defense included just a single challenger and a single defender. Today, 10 or more vessels typically compete over a period of several months prior to the defense, with related competitions and regattas taking place around the world in the years prior to the defense. The competition is held in three to four year intervals, with the winner of each Cup gaining the right to determine in the essential elements of the following competition. In particular, the defender determines where the next race series will be held, the parameters of the series, and restrictions on boat design.

The most recent races have taken place in Valencia-Spain (2010, 2007), Auckland-New Zealand (2003, 2000), San Diego-California (1995, 1992, 1988), and Fremantle-Australia (1987, 1983).

From the 7th to the 15th of April 2012, Naples opened the circuit of World Series of the 34th American's Cup. Table 2 summarizes the benefits resulting from staging the Cup according to the proposed framework of Table 1. These benefits are further discussed below.

America's Cup improved Naples' credibility in the global marketplace showing both the natural beauty and the touristic attractions of the city. The Cup helped put Naples under the international light and rebranded the city in the world stage. It also improved the image of policy makers involved in the project to enhance the city's image. 
It facilitated the collaboration across policy makers involving leaders at national, regional, and local level who cooperated for staging the event. Policy makers also authorized funds to improve control on the city's center to reduce criminal behavior. Thus, America's Cup was used to address problems such as crime and urban decay.

It also represented an opportunity for development and change for the entire territory, increasing business activity in surrounding communities and generating image benefits through the global exposure by the media.

The economic benefits of America's Cup came primarily through spending on hotels, restaurants, and retail and other services by both tourists and residents. During the days of America's Cup, occupancy rates averaged roughly 85\%. Waterfront restaurants benefited from Cup activity. The Cup drew a significant number of international visitors, who spent more per capita than city residents. Restaurants captured half of any increase in visitor spending in the city. The Cup offered an excellent opportunity to attract tourists to the city, and to draw many residents and visitors in via Caracciolo.

However, despite the political, economical, and socio-cultural positive effects of the event, no long-term investments, nor policies for protecting the city's natural beauties or supporting its touristic development were realized. At the end of the event, the question that remains is whether America's Cup has been able to initiate a long-term process of touristic development for Naples.

Table 2

Main Effects of 34th America's Cup on Naples

\begin{tabular}{|l|l|}
\hline Credibility in the global marketplace & Yes \\
\hline Image of the government and leaders & Yes \\
\hline Cooperation across political and government and between public and private sectors & Yes \\
\hline Address social problems such as crime and urban decay & Yes \\
\hline Jolt to the economy & Yes \\
\hline Opportunity to change & Yes \\
\hline Infrastructure & No \\
\hline
\end{tabular}

\section{Conclusions and Discussion}

The America's Cup World Series has been an ideal event for initiating the process of renewing the image of Naples. The event brought resources to Naples and drew international media attention. Thus, it can be considered as an important step towards re-launching the image of Naples and of the region of Campania in the global marketplace. It also reinforced the trust to the leaders of the city that had to work together to stage the event. A significant number of stakeholders joined forces to deliver the event, including the Region of Campania, the Province of Naples, the City of Naples and Unione Industriali Napoli. The event was used to address problems such as crime and urban decay. All local authorities demonstrated a deep passion for the city of Naples and bringing the events to the region. The Cup also sparked some economic development. It promoted tourism and trade, enhancing the image of Naples internationally as a tourist destination. It also gave the Italian public an opportunity to watch the world's top sailors compete in the state-of-the-art-AC45 wing-sailed catamarans. In summary, 34th America's Cup offered Naples an opportunity to change. However, considering the fact that minimal infrastructural investments were realized, the question to be answered in the 
future is whether the 34th America's Cup has been able to give the start to a long-term process of development of Naples.

\section{References}

Deccio, C., \& Baloglu, S. (2002). Nonhost community resident reactions to the 2002 Winter Olympics: The spillover impacts. Journal of Travel Research, 41(1), 46-56.

Getz, D. (1997). Event management and event tourism. New York: Cognizant Communication.

Hall, C. M. (1989). Hallmark tourist events: Analysis, definition, methodology and review. In G. J. Syme, B. J. Shaw, D. M. Fenton, \& W. S. Mueller (Eds.), The planning and evaluation of hallmark events. Sydney, Australia: Avebury.

Hall, C. M. (1992). Hallmark tourist events: Impact, management, and planning. London: Belhaven Press.

Jeong, G. H., \& Faulkner, B. (1996). Resident perceptions of megaevent impacts: The Taejon international exposition case. Festival Management and Event Tourism, 4(1), 3-11.

Kang, Y. S., \& Perdue, R. (1994). Long-term impact of a mega-event on international tourism to the host country: A conceptual model and the case of the 1988 Seoul Olympics. Journal of International Consumer Marketing, 6(3-4), 205-226.

Mihalik, B. J., \& Simonette, L. (1998). Resident perceptions of the 1996 Summer Olympic Games-Year II. Festival Management and Event Tourism, 5(1), 9-19.

Murphy, P. E., \& Carmichael, B. A. (1991). Assessing the tourism benefits of an open access sports tournament: The 1989 B.C. Winter Games. Journal of Travel Research, 29(3), 32-35.

Ritchie, J. R. B. (1984). Assessing the impact of hallmark events: Conceptual and research issues. Journal of Travel Research, 22(1), 2-11.

Ritchie, J. R. B., \& Aitken, C. E. (1984). Assessing the impacts of the 1988 Olympic Winter Games: The research program and initial results. Journal of Travel Research, 22(3), 17-25.

Ritchie, J. R. B., \& Aitken, C. E. (1985). Olympulse II: Evolving resident attitudes toward the 1988 Olympic Winter Games. Journal of Travel Research, 23(1), 28-33.

Ritchie, J. R. B., \& Lyons, M. (1990). Olympulse VI: A post-event assessment of resident reactions to the XV Olympic Winter Games. Journal of Travel Research, 28(3), 14-23. 